Volume 1 Issue 2, September 2017: pp. 220-245. Copyright (c) 2017 HOLREV. Faculty of Law, Halu Oleo University, Kendari, Southeast Sulawesi, Indonesia. ISSN: 2548-1762 | e-ISSN: 2548-1754. Open Access at: http://ojs.uho.ac.id/index.php/holrev/

Halu Oleo Law Review is licensed under a Creative Commons Attribution 4.0 International License, which permits unrestricted use, distribution, and reproduction in any medium, provided the original work is properly cited.

\title{
Tinjauan Yuridis tentang Kriteria Pencemaran dan Perusakan Lingkungan Menurut UU No. 32 Tahun 2009 Tentang Pengelolaan Lingkungan Hidup
}

\author{
Legal Analysis for Criteria of Contamination and \\ Environmental Damage Based on Laws 32 Year 2009 \\ Environmental Management
}

\author{
Nikmah Fitriah \\ Dosen Sekolah Tinggi Ilmu Hukum (STIH) Sultan Adam Banjarmasin \\ E-mail: azissinggih000@gmail.com
}

\begin{abstract}
The study, entitled: "Overview of Juridical About Pollution and Environmental Criteria According to Law No. 32 Year 2009 on the Management of Environmental Protection "aims to do the comparison criteria between environmental pollution and destruction of Law No. 23 of 1999 by Law No. 32 of 2009 and analyze changes in criteria for pollution and environmental destruction in Law 32 of 2009 in sync with life. Environmental science theory method used in this research is the type of research is a kind of normative research is to do research on various laws and regulations either about discrepancies, as well as issues of contention legislation. Results of this research note that the first, from a comparison of the criteria pollution and environmental damage, the version of Law No. 23 of 1999 by Law No. 32 of 2009 resulted in a difference in determining whether a criminal offense. Version of Law No. 23 of 1999, the crime of pollution and environmental destruction including materiel offense categories, thus in the process of proof demanded two things proved it was committed by a perpetrator who is able to be responsible and also proved such actions lead to a result which is prohibited by law, While the version of Law No. 32 In 2009, the crime of pollution and environmental destruction including formal offense category, so it is only necessary to prove a prohibited act alone. Secondly, it is known that pollution and environmental criteria, according to Law No. 32 Year 2009 contradictory or out of sync with the criteria based on the theory of environmental or ecological criteria.
\end{abstract}

Keywords: Legal Analysis, of Contamination and Environmental Damage, Environmental Management.

Abstrak: Penelitian yang berjudul: "Tinjauan Yuridis Tentang Kriteria Pencemaran dan Perusakan Lingkungan Menurut UU No. 32 Tahun 2009 Tentang Pengelolaan Lingkungan Hidup" ini bertujuan untuk melakukan perbandingan kriteria pencemaran dan perusakan lingkungan antara UU No. 23 Tahun 1999 dengan UU No. 32 Tahun 20/09 dan menganalisis perubahan kriteria pencemaran dan 
perusakan lingkungan dalam UU No. 32 Tahun 2009 sinkron dengan teori ilmu lingkungan hidup. Metode yang digunakan dalam penelitian ini adalah Jenis penelitian yang digunakan adalah jenis penelitian normatif yaitu melakukan telaah terhadap berbagai peraturan perundang-undangan baik mengenai ketidaksinkronan, maupun masalah pertentangan peraturan perundang-undangan. Hasil dari penelitian ini diketahui bahwa pertama, dari perbandingan kriteria pencemaran dan kerusakan lingkungan, versi UU No. 23 tahun 1999 dengan UU No. 32 Tahun 2009 menghasilkan suatu perbedaan dalam menentukan suatu tindak pidana. Versi UU No. 23 Tahun 1999, tindak pidana pencemaran dan perusakan lingkungan termasuk kategori delik materiel, sehingga dalam proses pembuktiannya dituntut dua hal yaitu terbukti perbuatan tersebut dilakukan oleh pelaku yang mampu bertanggungjawab dan harus pula dibuktikan perbuatan tersebut menimbulkan akibat yang dilarang oleh undang-undang. Sedangkan versi UU No. 32 Tahun 2009, tindak pidana pencemaran dan perusakan lingkungan termasuk kategori delik formal, sehingga hanya perlu dibuktikan suatu perbuatan yang dilarang saja. Kedua, diketahui kalau kriteria pencemaran dan perusakan lingkungan menurut UU No. 32 Tahun 2009 bertentangan atau tidak sinkron dengan kriteria berdasarkan teori lingkungan hidup atau kriteria secara ekologis

Kata kunci: Tinjauan Yuridis, Pencemaran dan Perusakan Lingkungan, Pengelolaan Lingkungan Hidup.

\section{PENDAHULUAN}

Undang-Undang Nomor 32 Tahun 2009 tentang Pengelolaan Lingkungan Hidup atau lebih dikenal sebagai Undang-Undang Pengelolaan Lingkungan Hidup (UUPLH) diundangkan sebagai pengganti dari Undang-Undang Nomor 23 Tahun 1997. (Selanjutnya disebut UU No. 32 Tahun 2009). Sebagai aturan dasar dalam pengelolaan lingkungan hidup, maka UU No. 32 Tahun 2009 pada aspek norma hukumnya telah menetapkan adanya sanksi terhadap para pelaku perusakan dan pencemaran lingkungan hidup. Sanksi hukum adalah hal yang sangat urgen dalam suatu undang-undang, oleh karena dengan sanksilah sehingga suatu undang-undang mempunyai energi untuk dilaksanakan.

Salah satu perbuatan yang bisa dikenakan sanksi dari UU No. 32 Tahun 2009 adalah perbuatan yang bisa mengakibatkan pencemaran dan perusakan lingkungan. Definisi dari pencemaran lingkungan menurut Pasal 1 ayat (14) UU No. 32 Tahun 2009 adalah "masuknya atau dimasukkannya makhluk hidup, zat, energi, dan/atau komponen lain ke dalam lingkungan hidup oleh kegiatan manusia sehingga melampaui baku mutu lingkungan hidup yang ditetapkan." Kemudian definisi perusakan lingkungan menurut Pasal 1 ayat (16) UU No. 32 Tahun 2009 adalah "tindakan orang yang menimbulkan perubahan-perubahan langsung atau tidak langsung terhadap sifat fisik, kimia, dan/atau hayati lingkungan hidup sehingga melampaui kriteria baku kerusakan lingkungan hidup." 
Perbedaan antara perusakan pencemaran dan lingkungan adalah kalau pada kasus perusakan lingkungan maka yang turun kualitasnya atau yang bermasalah adalah seluruh komponen lingkungan baik yang bersifat hayati maupun fisik sedangkan pada kasus pencemaran lingkungan yang bermasalah atau yang turun kualitasnya hanya salah satu komponen saja. Sehingga pada kasus pencemaran lingkungan dikenal istilah pencemaran air, kalau yang turun kualitasnya adalah komponen air, pencemaran tanah, kalau yang turun kualitasnya adalah komponen tanah atau pencemaran udara, kalau yang turun kualitasnya adalah komponen udara.

Aspek larangan berbuat yang disertai ancaman pidana dalam artian ini sering disebut dengan tindak pidana atau perbuatan pidana (berasal dari katastrafbaarfeit), yang juga sering disebut delik (berasal dari kata delict). Tindak pidana merupakan rumusan tentang perbuatan yang dilarang untuk dilakukan (dalam peraturan perundangundangan) yang disertai ancaman pidana bagi siapa yang melanggar larangan tersebut. Jadi, perbuatan (feit) di sini adalah unsur pokok dari suatu tindak pidana yang dirumuskan tersebut.

Namun dalam hal pertanggungjawaban tindak pidana untuk bisa meminta pertanggungjawaban seseorang, maka harus cukup bukti yang bisa membuktikan unsur kesalahan pelaku atas suatu tindakan yang orang tersebut lakukan. Jadi masalah pembuktian memegang perkara penting dalam penegakan hukum pidana.

Masalah membuktikan dalam pertanggungjawaban hukum pidana aspek hukum lingkungan bukanlah hal yang gampang. Apalagi dalam hal pembuktian tindak pidana untuk kategori pencemaran lingkungan hidup. Pembuktiannya tidak bisa dengan kasat mata. Untuk bisa membuktikan memang benar telah terjadi pencemaran lingkungan maka harus melibatkan para ahli yang berkompeten di bidangnya seperti seorang analis yang ahli di bidang ilmu kimia yang bisa membuktikan keberadaan suatu zat asing dalam suatu lingkungan telah melebihi nilai ambang batas yang ditetapkan dalam baku mutu lingkungan hidup.

Lahirnya UU No. 32 Tahun 2009 sebagai pengganti UU No. 23 Tahun 1997 membuat terobosan baru dalam penegakan hukum lingkungan agar lebih mudah dalam masalah pembuktian suatu perkara hukum lingkungan. Terobosan tersebut adalah mengubah pertanggungjawaban hukum pidana yang tadinya masuk dalam kategori delik materiel menjadi delik formil untuk perbuatan pencemaran dan perusakan lingkungan. Jadi itu berarti tidak perlu lagi dibuktikan unsur akibatnya dari suatu perbuatan tapi cukup 
dibuktikan adanya perbuatan yang dianggap dinyatakan sebagai suatu perbuatan yang dilarang, yang apabila dilakukan maka akan mendapatkan sanksi sesuai dengan peraturan perundang-undangan.

Dalam hal ini, niat baik dari perumus peraturan perundang-undangan dalam hal membuat terobosan untuk masalah pembuktian tindak pidana hukum lingkungan perlu mendapat aspirasi, namun tentunya terobosan tersebut haruslah sesuai dengan prinsipprinsip yang terdapat dalam teori lingkungan hidup. Penelitian ini dilakukan untuk meneliti hal tersebut yaitu masalah sinkronisasi perumusan pencemaran dan perusakan lingkungan hidup dalam UU No. 32 Tahun 2009 dengan teori lingkungan hidup.

\section{ANALISIS DAN PEMBAHASAN}

\section{Konsep Kriteria tentang Masalah Lingkungan Hidup}

Salah satu unsur lingkungan adalah keadaan. Dan keadaan ini adakalanya dalam kondisi yang baik dalam artian keadaan tersebut membantu kelancaran berlangsungnya proses kehidupan, akan tetapi keadaan tersebut dalam kondisi yang tidak baik, yaitu keadaan tersebut mengganggu berprosesnya interaksi lingkungan dengan baik. Tolak ukurnya adalah masalah keseimbangan atau keharmonisan yang sifatnya adalah alami dan mutlak. Jadi lingkungan dikatakan bermasalah apabila dalam lingkungan hidup tersebut tidak ada jalinan interaksi yang seimbang dan harmonis antara komponen-komponen lingkungan hidup, yaitu apabila fungsi-fungsi di dalam mata rantai ekosistem terganggu dan gangguan itu melampaui kemampuan ekosistem untuk memulihkan diri secara alami.

Dalam menimbulkan masalah lingkungan hidup, manusia adalah merupakan komponen yang paling dominan, karena manusia mempunyai konstruksi yang paling sempurna jika dibanding dengan komponen-komponen yang lain. Kelebihan manusia adalah manusia memiliki akal dan budi. Kemudian manusia memiliki keinginan yang tidak ada pernah habis-habisnya.

Menurut Harun M. Husein ada dua macam pandangan manusia terhadap lingkungan hidupnya yaitu:

1. Pandangan immanen yaitu pandangan yang menempatkan manusia dan lingkungan hidupnya dalam hubungan yang bersifat fungsional. Ciri-cirinya:

a. kehidupannya masih sederhana dimana manusia meletakkan lingkungan hidupnya sejajar di sampingnya. 
b. dalam masyarakat ini masih berkembang berbagai kebiasaan yang bersifat mitos dan mistik.

2. Pandangan transenden yaitu pandangan yang menempatkan lingkungan hidupnya sebagai suatu obyek yang harus dieksploitasi seoptimal mungkin guna memenuhi kebutuhan dan keinginannya.

Ciri-cirinya:

a. peradaban manusia sudah maju yaitu manusia sudah menentukan dan menguasai teknologi, dimana dengan ilmu pengetahuan dan teknologi tersebut manusia berusaha menundukkan alam.

b. telah terjadi pergeseran nilai, terutama nilai interaksi manusia dengan lingkungan hidupnya. ${ }^{1}$

Akibat ulah manusia yang mengeksploitasi alam tanpa kendali, maka memberikan tekanan yang semakin lama semakin berat kepada daya dukung lingkungan hidup. Dalam Pasal 1 ayat (7) UU No. 32 Tahun 2009, berbunyi “Daya dukung lingkungan hidup adalah kemampuan lingkungan hidup untuk mendukung perikehidupan manusia, makhluk hidup lain, dan keseimbangan antar keduanya."

Pola dan potensi ancaman ekologis menurut NHT Siahaan dalam Harun M. Husein, terhadap lingkungan hidupnya adalah:

1. Pola Individual yaitu bahwa setiap sosok manusia memiliki potensi-potensi memberikan dampak lingkungan yang bersumber dari keinginan. Perbuatanperbuatan itu terjadi karena dipengaruhi:

a. Faktor-faktor ketiadaan perangkat norma yang mengatur interaksiinteraksi individu dan lingkungan hidupnya.

b. Faktor ketiadaan sarana-sarana pembinaan lingkungan

c. Faktor egoisme

d. Faktor ketiadaan atau kurangnya pengawasan dan penegakan hukum.

2. Pola Politik Pembangunan (Negara Berkembang) Umumnya di negara-negara yang sedang berkembang para pemerintahnya berusaha meningkatkan kesejahteraan ekonomi dan sosial masyarakat di segala bidang kehidupan melalui berbagai upaya. Misalnya membuka kebijakan baru untuk menarik investasi asing menanamkan modal, imporisasi barang-barang, mendaya

1 Harun. M. Husein, Lingkungan Hidup, Masalah, Pengelolaan dan Penegakan Hukumnya, Jakarta: Bumi Aksara, 1995, h. 19-20. 
gunakan sumber daya alam untuk mendukung sistem pembangunan tanpa memikirkan efek sampingnya buat lingkungan. Akibatnya pencemaran dan perusakan lingkungan sebagai akibat dari over eksploitasi sumber daya alam.

3. Pola Negara-negara Maju/Negara-negara Industri Umumnya negara-negara maju memanfaatkan ambisi negara berkembang untuk sejajar dengan negara maju dengan sikap masa bodoh, untuk lebih meningkatkan industri dan perdagangan negaranya. Dan karena kemampuan ekonomi negara berkembang yang belum kuat maka umumnya industri yang diekspor negara maju adalah industri yang tidak diperlukan lagi di negara-negara maju, atau industri yang mengandung bahaya pencemaran dan resiko besar, juga industri yang menghasilkan barang-barang konsumsi bagi elite kecil yang meniru pola hidup elite negara maju. ${ }^{2}$

Aktivitas manusia yang menimbulkan perubahan pada lingkungan hidupnya disebut dampak lingkungan. Definisinya terdapat dalam Pasal 1 ayat (26) UU No. 32 Tahun 2009 yang berbunyi "Dampak lingkungan hidup adalah pengaruh perubahan pada lingkungan hidup yang diakibatkan oleh suatu usaha dan/atau kegiatan. " Apabila dampak lingkungan itu menimbulkan manfaat terhadap lingkungan maka disebut dampak lingkungan yang positif. Akan tetapi apabila menimbulkan resiko buat lingkungan maka dampak lingkungan tersebut disebut dampak lingkungan yang negatif.

\section{Perwujudan Masalah-Masalah Lingkungan}

Perwujudan dari masalah lingkungan bisa berupa pencemaran maupun perusakan lingkungan. Definisi dari pencemaran lingkungan menurut Pasal 1 ayat (14) UU No. 32 Tahun 2009 adalah "masuknya atau dimasukkannya makhluk hidup, zat, energi, dan/atau komponen lain ke dalam lingkungan hidup oleh kegiatan manusia sehingga melampaui baku mutu lingkungan hidup yang ditetapkan." Kemudian definisi perusakan lingkungan menurut Pasal 1 ayat (16) UU No. 32 Tahun 2009 adalah "tindakan orang yang menimbulkan perubahan-perubahan langsung atau tidak langsung terhadap sifat fisik, kimia, dan/atau hayati lingkungan hidup sehingga melampaui kriteria baku kerusakan lingkungan hidup." 


\section{Tolok Ukur Pencemaran dan Perusakan Lingkungan Hidup}

Untuk menentukan apakah lingkungan hidup telah tercemar atau tidak dan apakah telah terjadi perusakan lingkungan atau tidak, harus ditetapkan kriteria yang dapat dipergunakan sebagai tolok ukur.

Tolok ukur yang menjadi kriterianya adalah:

\section{Kriteria ekologis pencemaran/perusakan lingkungan hidup}

Secara ekologis menurut Otto Soemarwoto lingkungan telah tercemar apabila terpenuhi dua syarat yaitu: “(1). kalau suatu zat, organisme atau unsur-unsur yang lain (seperti gas, cahaya, energi) telah tercampur ke dalam sumber daya/lingkungan tertentu. (2). Dan karenanya menghalangi/mengganggu fungsi atau peruntukan daripada sumber daya/lingkungan tersebut."3

Kedua syarat tersebut mutlak harus dipenuhi, karena bila hanya nomor satu saja maka baru terjadi pengotoran yaitu perubahan kualitas sumber daya sebagai akibat tercampurnya bahan lain tanpa mengganggu peruntukan/kegunaannya.

Empat faktor atau empat hal penyebab terjadinya pencemaran yaitu:

a. Lebih besarnya kecepatan produksi suatu zat daripada kecepatan penggunaannya secara kimia fisik. (barang sintetis)

b. Proses biologi yang membentuk/mengonsentrasikan zat pencemar tertentu. (rantai makanan)

c. Berdasarkan proses fisika kimia non biologi. (gunung berapi meletus)

d. Terjadinya kecelakaan yang dapat melepaskan ke dalam lingkungan bisa terjadi seketika atau lambat laun. (Kapal menyangkut minyak tumpah di laut). 4

Menurut Harun M. Husein, secara ekologis, lingkungan telah rusak apabila:

Telah terjadi suatu aktivitas terhadap lingkungan atau kehadiran bendabenda asing ke dalam lingkungan, menimbulkan gangguan pada ekosistem lingkungan, yang menyebabkan timbulnya perubahan pada sifat-sifat fisik dan atau hayati lingkungan, sehingga karenanya fungsi lingkungan sebagai sarana pendukung terlanjutkannya pembangunan tidak atau kurang terpenuhi. 5

\footnotetext{
Otto Soemarwoto, Ekologi, Lingkungan hidup dan Pembangunan, Jakarta: Djambatan, 1989, h. 17.

NHT. Siahaan, Ekologi Pembangunan dan Hukum Tata Lingkungan, Jakarta: Erlangga, 1987, h. 159-160.

Harun. Husein, Op.Cit, h. 64
} 


\section{Kriteria Yuridis Pencemaran/Perusakan Lingkungan Hidup}

Yang dimaksudkan dengan kriteria yuridis, ialah perumusan pencemaran/ perusakan lingkungan menurut ketentuan Undang-Undang Nomor 32 Tahun 2009 tentang Pengelolaan Lingkungan Hidup:

\section{Pencemaran Lingkungan Hidup}

Menurut ketentuan Pasal ayat (14) UU No. 32 Tahun 2009 "pencemaran lingkungan adalah masuknya atau dimasukkannya makhluk hidup, zat, energi, dan/atau komponen lain ke dalam lingkungan hidup oleh kegiatan manusia sehingga melampaui baku mutu lingkungan hidup yang ditetapkan."

Perusakan Lingkungan Hidup

Menurut Pasal 1 ayat (16) UU No. 32 Tahun 2009, "perusakan lingkungan adalah tindakan orang yang menimbulkan perubahan-perubahan langsung atau tidak langsung terhadap sifat fisik, kimia, dan/atau hayati lingkungan hidup sehingga melampaui kriteria baku kerusakan lingkungan hidup."

Untuk lebih jelasnya mengenai tolok ukur pencemaran/ perusakan lingkungan hidup secara yuridis kita perlu melihat ketentuan mengenai Baku.

Mutu Lingkungan (BML), yaitu:

1) Keputusan Nomor: KEP-02/MENKLH/1/1988 tentang Pedoman Penetapan Baku Mutu Lingkungan

2) Keputusan Nomor: KEP-/MENKLH/11/1991 tentang Baku Mutu Limbah Cair.

BML berfungsi sebagai tolok ukur untuk mengetahui apakah telah terjadi perusakan atau pencemaran lingkungan. Gangguan terhadap lingkungan diukur menurut besar kecilnya penyimpangan dari batas-batas yang ditetapkan sesuai dengan kemampuan atau daya tenggang ekosistem lingkungan.

Batas-batas daya dukung lingkungan disebut nilai ambang batas (NAB). NAB menurut NHT. Siahaan adalah batas tertinggi (maksimum) dari kandungan zat-zat, makhluk hidup atau komponen-komponen lain yang dapat atau yang diperbolehkan dalam setiap interaksi yang berkenaan dengan lingkungan. ${ }^{6}$

Dari pengertian di atas kita bisa menyimpulkan bahwa ekosistem telah tercemar/rusak, apabila ternyata kondisi lingkungan itu telah melebihi NAB yang ditentukan berdasarkan baku mutu lingkungan.

6 NHT. Siahaan, Op.Cit, h. 163 


\section{Pengertian Dasar Tentang Delik dan Pembagian Menurut Jenis-Jenisnya}

Hukum pidana Belanda memakai istilah strafbaar feit, kadang-kadang juga delict yang berasal dari bahasa Latin delictum. Hukum pidana negara-negara Anglo-Saxon memakai istilah offense atau criminal act untuk maksud yang sama. Oleh karena KUHP Indonesia bersumber pada WvS Belanda, maka istilah aslinya pun sama yaitu strafbaar feit. Timbullah masalah dalam menerjemahkan istilah strafbaar feit itu ke dalam bahasa Indonesia. Moeljatno dan Roeslan Saleh memakai istilah perbuatan pidana meskipun tidak untuk menerjemahkan strafbaar feit itu. Utrecht, menyalin istilah strafbaar feit menjadi peristiwa pidana. Rupanya Utrecht menerjemahkan istilah feit secara harfiah menjadi peristiwa. Sama dengan istilah yang dipakai oleh Utrecht, UUD Sementara 1950 juga memakai istilah peristiwa pidana. ${ }^{7}$

Sekarang ini semua undang-undang telah memakai istilah tindak pidana, seperti Undang-Undang Tindak Pidana Ekonomi, Undang-Undang Tindak Pidana Imigrasi, Undang-Undang Tindak Pidana Suap, dan seterusnya. Istilah tindak pidana itu pun tidak disetujui oleh Moeljatno, antara lain dikatakan bahwa "tindak" sebagai kata tidak begitu dikenal, maka perundang-undangan yang memakai kata "tindak pidana" baik dalam pasalpasalnya sendiri, maupun dalam penjelasannya hampir selalu memakai pula kata "perbuatan". ${ }^{8}$ Moeljatno mengatakan, bahwa perbuatan pidana itu dapat disamakan dengan criminal act, jadi berbeda dengan strafbaar feit, yang meliputi pula pertanggungjawaban pidana. Katanya, criminal act itu berarti kelakuan dan akibat, yang disebut juga actus reus. ${ }^{9}$

A.Z. Abidin dalam Erliany, mengusulkan pemakaian istilah "perbuatan kriminal”, karena "perbuatan pidana" yang dipakai oleh Moeljatno itu juga kurang tepat, karena dua kata benda bersambungan yaitu "perbuatan" dan "pidana”, sedangkan tidak ada hubungan logis antara keduanya. Jadi, meskipun ia tidak sama istilahnya dengan Moeljatno, tetapi keduanya rupanya dipengaruhi oleh istilah yang dipakai di Jerman, yaitu "Tat" (perbuatan) atau "handlung" dan tidak dengan maksud untuk menerjemahkan kata "feit" dalam bahasa Belanda itu. Tetapi A.Z. Abidin menambahkan bahwa lebih baik dipakai istilah padanannya saja, yang umum dipakai oleh para sarjana, yaitu delik (dari bahasa Latin delictum). Memang jika kita perhatikan hampir semua penulis memakai juga istilah "delik" di

7 Moeljatno, Perbuatan Pidana dan Pertanggungan Jawab Dalam Hukum Pidana. Yogyakarta: Yayasan Badan Penerbit Gajah Mada, 1959, h. 7.

$8 \quad$ Ibid

9 Ibid 
samping istilahnya sendiri seperti Roeslan Saleh di samping memakai "perbuatan pidana" juga memakai istilah "delik", begitu pula Oemar Seno Adji, di samping memakai istilah "tindak pidana" juga memakai istilah "delik". 10

Simons dalam Erliany, merumuskan delik, bahwa strafbaar feit ialah kelakuan yang diancam dengan pidana, yang bersifat melawan hukum yang berhubungan dengan kesalahan dan dilakukan oleh orang yang mampu bertanggung jawab. Kemudian Van Hamel merumuskan delik (strafbaar feit) itu sebagai berikut: eene wettelijke omschreven menschelijke gedraging, onrechtmatig, strafwaardig en aan schuld te wijten (kelakuan manusia yang dirumuskan dalam undang-undang, melawan hukum, yang patut dipidana dan dilakukan dengan kesalahan. ${ }^{11}$

Pada umumnya rumusan suatu delik berisi "bagian inti” (bestand delen) suatu delik. Artinya, bagian-bagian inti tersebut harus sesuai dengan perbuatan yang dilakukan, barulah seseorang diancam dengan pidana. Banyak penulis menyebut ini sebagai unsur delik. Tetapi di sini, tidak dipakai istilah "unsur delik", karena unsur (element) suatu delik ada juga di luar rumusan, misalnya delik pencurian terdiri dari bagian inti (bestanddelen): mengambil, barang yang seluruhnya atau sebagian kepunyaan orang lain, dengan maksud memiliki, melawan hukum. Keempat bagian inti delik ini harus sesuai dengan perbuatan nyata yang dilakukan. Oleh karena itu harus termuat di dalam surat dakwaan. Apabila satu atau lebih bagian inti ini tidak dapat dibuktikan di Sidang Pengadilan, maka terdakwa bebas. ${ }^{12}$

Delik itu dapat dibedakan atas pelbagai pembagian tertentu, seperti berikut ini:

1. Delik kejahatan dan delik pelanggaran (misdrijven en over-tredingen).

2. Delik materiel dan delik formal (materiele en formelede-licten).

Pada delik materiel, disebutkan adanya akibat tertentu, dengan atau tanpa menyebut perbuatan tertentu. Pada delik formal, disebut hanya suatu perbuatan tertentu sebagai dapat dipidana misalnya Pasal 160, 209, 242, 263, 362 KUHP.

3. Delik komisi dan delik omisi (commissiedelicten en omis-siedelicten).

4. Delik yang berdiri sendiri dan delik yang diteruskan (Zelfs-tandige en voorgezette delict en).

10 Erliany, Op.Cit, h. 100-101

11 Ibid, h. 102

12 Ibid, h. 109 
5. Delik selesai dan delik berlanjut (aflopende en voortduren-de delicten).

6. Delik tunggal dan delik berangkai (enkelvoudige en samen-gestelde delicten).

7. Delik bersahaja dan delik berkualifikasi (ecnvoudige en gequalificeerde delicten).

8. Delik sengaja dan delik kelalaian atau culpa (Doleuse en culpose delicten).

9. Delik politik dan delik komun atau umum (politieke en commune delicten).

10. Delik propria dan delik komun atau umum (delicta prop ria en commune delicten).

11. Delik-delik dapat dibagi juga atas kepentingan hukum yang dilindungi, seperti delik terhadap keamanan negara, delik terhadap orang, delik kesusilaan, delik terhadap harta benda dan lain-lain.

12. Untuk Indonesia, menurut Kitab Undang-undang Hukum Acara Pidana Pasal 284, dikenal pula delik umum dan delik khusus, seperti delik ekonomi, korupsi, subversi dan lain-lain. ${ }^{13}$

\section{Perbandingan Kriteria Pencemaran dan Perusakan Lingkungan Hidup dalam UU No.}

\section{Tahun 1999 dengan UU No. 32 Tahun 2009}

Masalah pembuktian suatu perbuatan termasuk kategori tindak pidana atau bukan sangat memegang peranan penting dalam penerapan sanksi pidana kepada pelaku. Perbuatan pidana atau tindak pidana atau delik merupakan aspek larangan berbuat yang diatur dalam peraturan perundang-undangan yang disertai ancaman pidana, bagi siapa yang melanggar larangan tersebut. Jadi, perbuatan di sini adalah unsur pokok dari suatu tindak pidana yang dirumuskan tersebut.

Perbuatan-perbuatan yang ditentukan sebagai dilarang pada garis besarnya terdiri dari dua golongan, yaitu: (1) perbuatan-perbuatan aktif/ perbuatan positif yang sering juga disebut dengan perbuatan materiil (matriele feit); dan (2) perbuatan-perbuatan pasif/perbuatan negatif. ${ }^{14}$

Perbuatan materiil, yang adakalanya disebut dengan perbuatan jasmani ialah perbuatan yang untuk mewujudkannya disyaratkan adanya gerakan nyata dari tubuh atau bagian dari tubuh orang, misalnya memukul dengan gerakan tangan dan menyepak dengan gerakan kaki. Bagian yang terbesar tentang perbuatan yang dilarang dalam hukum

3 Ibid, h. 115

14 Erliany, Op.Cit, h. 6 
pidana adalah perbuatan aktif ini, yang penyebutannya dalam rumusan tindak pidana dilakukan dengan berbagai cara. ${ }^{15}$

Sementara itu, perbuatan pasif sesungguhnya berarti tidak melakukan perbuatan secara fisik, di mana hal tersebut justru melanggar suatu kewajiban hukum karena dituntut bagi yang bersangkutan untuk melaksanakan perbuatan tertentu. Seseorang dalam keadaan-keadaan dan dengan syarat-syarat tertentu oleh undang-undang diwajibkan untuk melakukan suatu perbuatan tertentu, yang apabila kewajiban hukum untuk berbuat itu diabaikannya, misalnya perbuatan "membiarkan dalam keadaan sengsara" (304), maka ia telah melakukan perbuatan pasif. Oleh karena itu: dia dijatuhi pidana. Norma hukum pidana yang berisi kewajiban hukum bagi seseorang yang dalam keadaan dan situasi tertentu untuk melakukan perbuatan tertentu disebut dengan tindak pidana pasif (tindak pidana omissionis atau omisiedelicten). ${ }^{16}$

Terdapatnya aturan yang jelas tentang perbuatan apa yang disebutkan sebagai suatu perbuatan yang dilarang untuk dilanggar, bisa jelas kita temukan dalam KUPH, maupun peraturan perundang-undangan lainnya di luar KUHP, yang memuat aspek pidana. Aspek larangan melakukan perbuatan tertentu yang disertai ancaman pidana bagi siapa yang melanggarnya, yang dalam aspek ini tidak dihubungkan dengan adanya si pembuat dan bisa tidaknya dipidana si pembuat tersebut.

Namun untuk menjatuhkan suatu sanksi pidana kepada seseorang tidak cukup hanya dengan menemukan telah terjadinya suatu perbuatan pidana yang dilarang peraturan perundang-undangan. Ada aspek lainnya yang harus dibuktikan yaitu aspek mengenai kesalahan (schuld) dan pertanggungjawaban pidana (toerekeningsvadbaarheid) pada diri si pembuat. Aspek hukum pidana dalam rumusan mengenai kesalahan (schuld) mengandung makna bahwa bagi si pembuat/penindak tersebut apakah ia benar dapat dijatuhi pidana ataukah tidak, bergantung dari apakah perbuatan yang nyata melanggar larangan itu dapat dipersalahkan ataukah tidak kepadanya. Artinya, apakah dia mempunyai kesalahan ataukah tidak. Jika dia tidak dapat dipersalahkan, maka terhadap perbuatannya yang nyata melanggar larangan itu tidak dapat dipertanggungjawabkan kepadanya, artinya pidana tidak boleh dijatuhkan kepadanya.

Dalam doktrin hukum pidana terdapat suatu asas mengenai hal ini yang dikenal dengan asas geen straf sender schuld (Belanda) atau keine strafobne schuld (Jerman) yang 
di Indonesia dikenal dengan asas tiada pidana tanpa kesalahan. Artinya, untuk dapatnya dipidana seseorang yang perbuatannya nyata melanggar larangan hukum pidana disyaratkan bahwa perbuatannya itu harus dapat dibuktikan dengan alat bukti yang sah, dapat dipersalahkan padanya atau dengan perkataan lain, si pembuat itu mempunyai kesalahan. ${ }^{17}$

Untuk membuktikan bersalah tidaknya seseorang terdakwa haruslah melalui pemeriksaan di depan sidang pengadilan, dalam hal pembuktian ini, Hakim perlu memperhatikan kepentingan masyarakat dan kepentingan terdakwa.

Kepentingan masyarakat berarti, bahwa seseorang yang telah melanggar ketentuan pidana (KUHP) atau undang-undang pidana lainnya, harus mendapat hukuman yang setimpal dengan kesalahannya. Sedangkan kepentingan terdakwa, berarti bahwa terdakwa harus diperlakukan secara adil sedemikian rupa, sehingga tidak ada seorang yang tidak bersalah mendapat hukuman.

Atau kalau memang ia bersalah jangan sampai mendapat hukuman yang terlalu berat, tetapi hukuman itu harus seimbang dengan kesalahannya. Socrates pernah mengungkapkan, bahwa "lebih baik melepaskan seribu orang penjahat, daripada menghukum seorang yang tidak bersalah". Demikianlah besarnya perhatian dan perlindungan yang hendak diberikan oleh hukum kepada orang yang tidak bersalah. ${ }^{18}$

Pasal 6 Undang-Undang Nomor: 14 Tahun 1970, secara tegas menyatakan, bahwa:

a. Tiada seorang juapun dapat dihadapkan di depan pengadilan, selain daripada yang ditentukan baginya oleh undang-undang.

b. Tiada seorang juapun dapat dijatuhi pidana, kecuali apabila pengadilan karena alat pembuktian yang menurut undang-undang, mendapat keyakinan bahwa seseorang dianggap dapat bertanggung-jawab, telah bersalah atas perbuatan yang dituduhkan atas dirinya.

Tujuan dari pasal ini adalah untuk menjamin terlaksananya hak asasi manusia. Setiap orang yang disangka, ditahan, dituntut atau dihadapkan di depan Pengadilan wajib dianggap tidak bersalah, selama belum ada putusan mempunyai kekuatan hukum tetap. Asas ini dikenal dengan Praduga Tak Bersalah (Persumption Of Inocence) (Pasal 8 UU No. 14/1970). Asas ini diwajibkan kepada semua pihak untuk tidak mendahului putusan pengadilan, untuk menyatakan kesalahan seseorang.

17 Ibid, h. 9-10

18 Susan, Op.Cit, h. 68 
Yang dimaksud dengan pembuktian, adalah pembuktian bahwa benar suatu peristiwa pidana telah terjadi dan terdakwalah yang bersalah melakukannya, sehingga harus mempertanggungjawabkannya. Untuk membuktikan kesalahan terdakwa, pengadilan terikat oleh cara-cara/ ketentuan-ketentuan pembuktian sebagaimana telah diatur dalam undang-undang.

Pembuktian yang sah harus dilakukan di sidang Pengadilan yang memeriksa terdakwa, pemeriksaan terhadap alat-alat bukti harus dilakukan di depan sidang. Tugas membuktikan adanya tindak pidana dari suatu perbuatan sampai menjatuhkan sanksi kepada si pelaku adalah tugas dari negara.

Salah satu contoh kasus yang bisa diambil adalah kasus terjadinya pencemaran air, di sungai Barito dan di sungai Martapura yang menurut penelitian kadar nilai dari zat pencemar di kedua sungai tersebut telah melebihi dari nilai ambang batas yang ditentukan dalam ketentuan Baku Mutu Lingkungan. Maka menjadi tugas negara untuk melakukan tindakan-tindakan yang berkaitan dengan hal tersebut seperti tindakan yang harus dan boleh dilakukan negara melalui alat-alat perlengkapannya (polisi) untuk memperjelas penyebab terjadinya pencemaran, tindakan untuk mencari pelaku yang bertanggung jawab atas terjadinya pencemaran itu, juga bagaimana perlakuan terhadap pelaku tersebut, begitu juga tentang bagaimana mencari alat-alat bukti untuk membuktikan kebenaran dugaan tersebut baik oleh penyidik (polisi) maupun oleh penuntut umum (jaksa), dan bagaimana hakim harus bersikap dan berbuat terhadap alat-alat bukti tersebut di persidangan dalam rangka menemukan hubungan kausalitas antara alat bukti yang ada dengan perbuatan pelaku sehingga hakim harus memutuskan apakah si pelaku bisa dipersalahkan atau tidak dan akhirnya hakimlah yang harus memutuskan apakah menjatuhkan atau tidak sanksi pidana kepada pelaku, sehingga tercapainya keadilan.

Teori tentang pembuktian ada empat (4) macam yaitu:

\section{Teori Pembuktian Positif}

Menurut teori ini, bahwa bersalah atau tidaknya terdakwa tergantung sepenuhnya kepada sejumlah alat bukti yang telah ditetapkan terlebih dahulu. Keyakinan hakim menurut teori ini harus dikesampingkan. Teori ini berkembang pada abad pertengahan, dan kini jarang diterapkan dalam praktek di pengadilan. 


\section{Teori Pembuktian Negatif}

Menurut teori ini hakim hanya boleh menjatuhkan pidana, apabila sedikit-dikitnya alatalat bukti yang telah ditentukan dalam undang-undang ada, ditambah keyakinan hakim yang diperoleh dari adanya alat-alat bukti itu. Bahwa terdakwa dapat dipersalahkan melakukan tindak pidana yang didakwakan kepadanya, apabila alat-alat bukti itu ada ditambah keyakinan hakim sendiri. KUHAP menganut teori ini.

\section{Teori Pembuktian Bebas}

Menurut teori ini alat-alat dan cara pembuktian tidak di tentukan dalam undang-undang. Teori ini mengakui adanya alat-alat bukti dan cara pembuktian. Akan tetapi tidak ditentukan atau tidak diatur dalam undang-undang.

\section{Teori Pembuktian Berdasarkan Keyakinan}

Menurut teori ini hakim menjatuhkan pidana semat-mata berdasarkan keyakinan pribadinya dan dalam putusan tidak perlu menyebut alasan-alasan putusannya. (R. Soesilo 1982:131). Asas pembuktian yang anut oleh KUHAP, adalah asas presumption of innocence (Asas Praduga tak bersalah). (Pasal 8 UU No. 14/1970). Dengan demikian dapat dimaklumi, bahwa hukum acara pidana Indonesia (KUHAP) menganut teori pembuktian negatif. Hal ini jelas dari bunyi pasal 183 KUHAP, sebagai berikut: hakim tidak boleh menjatuhkan pidana kepada seseorang, kecuali apabila dengan sekurang-kurangnya dua alat bukti yang sah, ia memperoleh keyakinan, bahwa suatu tindak pidana benar-benar terjadi dan bahwa Terdakwalah yang bersalah melakukannya. ${ }^{19}$

Menurut R. Atang Ranomiharjo yang dikutip Susan, alat-alat bukti yang sah, adalah alat-alat yang ada hubungannya dengan suatu tindak pidana, dimana alat-alat tersebut dapat dipergunakan sebagai bahan pembuktian, guna menimbulkan keyakinan bagi hakim, atas kebenaran adanya suatu tindak pidana yang telah dilakukan oleh terdakwa. ${ }^{20}$

Adapun alat-alat bukti yang sah menurut Pasal 184 (1) KUHAP, adalah sebagai berikut: 


\section{Keterangan saksi}

Keterangan saksi, adalah satu alat bukti dalam perkara pidana yang berupa keterangan dari saksi mengenai suatu peristiwa pidana yang ia alami sendiri, dengan menyebutkan alasan dari pengetahuannya itu (pasal 1 butir 27 KUHAP).

Dalam keterangan saksi tidak termasuk keterangan yang diperoleh dari orang lain atau Testimonium De Auditu. (Penjelasan Pasal 185 KUHAP).

1) Syarat Keterangan Saksi

Keterangan saksi supaya dapat dipakai sebagai alat bukti yang sah harus memenuhi dua syarat, yaitu:

a) Syarat Formil

Bahwa keterangan saksi hanya dapat dianggap sah, apabila ia diberikan di bawah sumpah. Keterangan saksi yang tidak di bawah sumpah hanya boleh dipergunakan sebagai penambah penyaksian yang sah.

b) Syarat Materiel

Bahwa keterangan seorang saksi saja tidak dapat dianggap sah sebagai alat pembuktian (Unus Testis Nulus Testis). Akan tetapi keterangan seorang saksi, adalah cukup untuk alat pembuktian salah satu unsur kejahatan yang dituduhkan.

Pengaturan lebih lanjut dari keterangan saksi sebagai pembuktian dapat di lihat seperti apa yang tercantum dalam Pasal 185 KUHAP, sebagai berikut:

(1) Keterangan saksi sebagai alat bukti, ialah apa yang saksi nyatakan disidang pengadilan;

(2) Keterangan seorang saksi saja tidak cukup untuk membuktikan bahwa terdakwa bersalah terhadap perbuatan yang didakwakan kepadanya;

(3) Keterangan sebagaimana yang dimaksud dalam ayat (2) tidak berlaku apabila disertai suatu alat bukti yang sah lainnya;

(4) Keterangan beberapa saksi yang berdiri sendiri-sendiri tentang suatu kejadian atau keadaan dapat dipergunakan sebagai suatu alat bukti yang sah apabila keterangan saksi itu ada hubungannya satu dengan yang lain sedemikian rupa, sehingga dapat memberikan adanya suatu kejadian atau keadaan tertentu;

(5) Baik pendapat maupun rekaan yang diperbolehkan dari hasil pikiran saja, bukan merupakan keterangan saksi; 
(6) Dalam menilai kebenaran keterangan saksi, hakim harus dengan sungguhsungguh memperhatikan:

a. Persesuaian antara keterangan saksi satu dengan yang lain;

b. Persesuaian antara keterangan saksi dengan alat bukti lain;

c. Alasan yang mungkin dipergunakan oleh saksi untuk memberikan keterangan yang tertentu;

d. Cara hidup dan kesusilaan saksi atau segala sesuatu yang pada umumnya dapat mempengaruhi dapat tidaknya keterangan itu dipercaya.

(7) Keterangan dari saksi yang tidak disumpah meskipun sesuai dengan yang lain, tidak merupakan alat bukti, namun apabila keterangan itu sesuai dengan keterangan saksi yang disumpah dapat dipergunakan sebagai tambahan alat bukti yang sah lainnya.

Dalam memeriksa saksi, Hakim, Penuntut Umum, Penasihat Hukum atau Terdakwa tidak boleh mengajukan pertanyaan yang menjerat atau yang bersifat atau mengarahkan saksi untuk memberikan jawaban tertentu. Pada prinsipnya saksi harus memberikan keterangan secara bebas di muka Hakim. (Pasal 166 KUHAP).

Penjelasan dari pasal tersebut menyatakan, bahwa jika dalam salah satu pertanyaan disebutkan suatu tindak pidana yang diakui telah dilakukan oleh terdakwa atau tidak dinyatakan oleh saksi, tetapi dianggap seolah-olah diakui dan dinyatakan, maka pernyataan yang sedemikian itu dianggap sebagai pertanyaan yang bersifat menjerat. Ini sesuai dengan prinsip, bahwa keterangan terdakwa atau saksi harus diberikan secara bebas di semua tingkat pemeriksaan.

Dalam pemeriksaan penyidik atau penuntut umum tidak boleh mengadakan tekanan yang bagaimanapun caranya, lebih-lebih di dalam pemeriksaan di sidang pengadilan. Tekanan itu misalnya ancaman dan sebagainya yang menyebabkan terdakwa atau saksi menerangkan hal yang berlainan daripada hal yang dapat dianggap sebagai pernyataan pikirannya yang bebas.

Menjadi saksi dalam perkara pidana adalah menjadi kewajiban dari setiap orang. Oleh karena itu orang yang menolak memberikan keterangannya 
sebagai saksi dalam suatu perkara pidana dapat dihadapkan ke sidang pengadilan. Pasal 159 (2) KUHAP menyatakan, bahwa dalam hal saksi tidak hadir, meskipun telah dipanggil dengan sah dan Hakim Ketua Sidang mempunyai cukup alasan untuk menyangka bahwa saksi itu tidak akan mau hadir, maka Hakim Ketua Sidang dapat memerintahkan supaya saksi tersebut dihadapkan ke persidangan.

2) Hal mengundurkan diri sebagai saksi

Menurut Pasal 168 KUHAP, bahwa yang tidak dapat di dengar keterangannya dan dapat mengundurkan diri sebagai saksi adalah:

a) Keluarga sedarah atau semenda dalam garis lurus ke atas atau ke bawah sampai derajat ketiga dari terdakwa atau yang bersama-sama sebagai terdakwa;

b) Saudara dari terdakwa atau yang bersama-sama sebagai terdakwa, saudara ibu atau saudara bapak, juga mereka yang mempunyai hubungan karena perkawinan dan anak-anak saudara terdakwa sampai derajat ketiga.

c) Suami atau istri terdakwa, meskipun sudah bercerai atau yang bersamasama sebagai terdakwa.

Menurut ketentuan Pasal 169 KUHAP, bahwa mereka sebagaimana dimaksud dalam Pasal 168 KUHAP, apabila menghendakinya dan penuntut umum serta terdakwa secara tegas menyetujuinya dapat memberikan keterangan tanpa disumpah.

Sedangkan menurut Pasal 170 KUHAP, yang dapat mengundurkan diri sebagai saksi, adalah mereka yang karena kerjaan, harkat martabat atau jabatannya diwajibkan menyimpan rahasia dapat minta dibebaskan dari kewajiban untuk memberikan keterangan sebagai saksi, yaitu tentang hal yang dipercayakan kepada mereka. Hakim menentukan sah atau tidaknya segala alasan untuk permintaan tersebut.

Dan orang-orang yang boleh diperiksa untuk memberikan keterangan tanpa disumpah menurut pasal 171 KUHAP, adalah anak yang umurnya belum cukup lima belas (15) tahun dan belum kawin, serta orang yang sakit ingatan atau sakit jiwa meskipun kadang-kadang ingatannya baik kembali. 


\section{Keterangan Ahli}

Keterangan ahli, adalah keterangan yang diberikan oleh seorang yang memiliki keahlian khusus tentang hal yang diperlukan untuk membuat terang tentang suatu perkara pidana, guna kepentingan pemeriksaan. (Pasal 1 butir 28 KUHAP).

Sedangkan menurut pasal 168 KUHAP, keterangan ahli ialah apa yang seorang ahli menyatakan disidang Pengadilan. Keterangan ahli itu dapat juga sudah diberikan pada waktu pemeriksaan oleh penyidik atau penuntut umum yang dituangkan dalam bentuk laporan dan dibuat mengingat sumpah di waktu menerima jabatan atau pekerjaan.

Jika hal itu tidak diberikan pada waktu pemeriksaan penyidik atau penuntut umum, maka pada saat pemeriksaan penyidik atau penuntut umum, maka pada pemeriksaan disidang diminta untuk memberikan keterangan dan dicatat dalam acara pemeriksaan. Keterangan tersebut diberitahukan setelah ia mengucapkan sumpah atau janji di hadapan Hakim. (Pasal 168 KUHP).

Penyidik karena kewajibannya mempunyai wewenang untuk mendatangkan seorang ahli yang diperlukan dalam hubungannya dengan pemeriksaan perkara (Pasal 7 (1) h KUHAP). Adapun ahli yang dimaksud dalam pasal ini, misalnya ahli kedokteran kehakiman, ahli balistik, ahli kimia, ahli fisika, ahli farmasi, ahli toxia dan lain-lain.

Bantuan yang dapat diberikan oleh para ahli tersebut, adalah untuk menjelaskan tentang bukti-bukti yang ada. Setiap orang yang diminta pendapatnya sebagai ahli kedokteran kehakiman atau dokter atau ahli-ahli lainnya wajib memberikan keterangan demi keadilan. Bantuan yang dapat diberikan oleh para ahli tersebut, adalah untuk menjelaskan tentang bukti-bukti yang ada.

Setiap orang yang diminta pendapatnya sebagai ahli kedokteran kehakiman atau dokter atau ahli lainnya, wajib memberikan keterangan demi keadilan. Semua ketentuan tersebut di atas untuk saksi berlaku juga bagi mereka yang memberikan keterangan ahli. Dengan ketentuan, bahwa mereka mengucapkan sumpah atau janji akan memberikan keterangan yang sebaik-baiknya dan yang sebenar-benarnya menurut pengetahuan dalam bidang keahliannya. (Pasal 179 KUHAP).

Pasal 180 (1) KUHAP menentukan, bahwa dalam hal diperlukan untuk menjernihkan duduk persoalan yang timbul disidang pengadilan, Hakim Ketua sidang dapat minta keterangan ahli dan dapat pula minta agar diajukan bahan baru oleh yang berkepentingan. Apabila timbul keberatan yang beralasan dari terdakwa atau Penasihat 
Hukum terhadap keterangan ahli, maka hakim dapat memerintahkan, agar hal itu dilakukan penelitian ulang (Pasal 180 (2) KUHAP).

Surat

Tentang alat bukti surat diatur dalam Pasal 187 KUHAP, sebagai berikut: Surat sebagaimana tersebut dalam Pasal 184 (1) c KUHAP, dibuat atas sumpah jabatan atau dikuatkan dengan sumpah, adalah:

1) Berita acara dan surat lain dalam bentuk resmi yang dibuat oleh Pejabat Umum yang berwenang atau yang dibuat di hadapannya yang memuat keterangan tentang kejadian atau keadaan yang didengar, dilihat atau yang dialaminya sendiri, disertai dengan alasan yang jelas dan tegas tentang keterangan itu;

2) Surat yang dibuat menurut ketentuan peraturan perundang-undangan atau surat yang dibuat oleh pejabat mengenai hal yang termasuk dalam tatalaksana yang menjadi tanggung jawabnya dan yang diperuntukkan bagi pembuktian sesuatu hal atau sesuatu keadaan;

3) Surat keterangan dari seorang ahli yang memuat pendapat berdasarkan keahliannya mengenai sesuatu hal yang atau sesuatu keadaan yang diminta secara resmi dari padanya;

4) Surat lain yang hanya dapat berlaku jika ada hubungannya dengan isi dari alat pembuktian yang lain.

Adapun contoh-contoh dari alat bukti surat itu, adalah BAP (Berita Acara Pemeriksaan) yang dibuat oleh Polisi, BAP Pengadilan, Berita Acara Penyitaan, Surat Perintah Penahanan, Surat Izin Penggeledahan, Surat Izin Penyitaan, dan lain-lainnya.

\section{Petunjuk}

Tentang petunjuk sebagai alat bukti diatur dalam Pasal 189 KUHAP, sebagai berikut:

1) Petunjuk adalah: perbuatan, kejadian atau keadaan yang karena penyesuaian, baik antara yang satu dengan yang lain, maupun dengan tindak pidana itu sendiri, menandakan bahwa telah terjadi suatu tindak pidana dan siapa pelakunya.

2) Petunjuk sebagaimana dimaksud dalam ayat (1), hanya dapat diperoleh dari:

(a) Keterangan saksi;

(b) Surat; 
(c) Keterangan terdakwa.

3) Penilaian atau kekuatan pembuktian dari suatu petunjuk dalam setiap keadaan tertentu dilakukan oleh hakim dengan arif lagi bijaksana, setelah ia mengadakan pemeriksaan dengan penuh kecermatan dan kesaksamaan berdasarkan hati nuraninya.

\section{Keterangan Terdakwa}

Pasal 189 KUHAP, mengatur tentang keterangan terdakwa sebagai berikut:

1) Keterangan terdakwa ialah: apa yang didakwakan nyatakan disidang tentang perbuatan yang dilakukan atau yang ia ketahui sendiri atau alami sendiri;

2) Keterangan terdakwa yang diberikan di luar sidang dapat digunakan untuk membantu menemukan bukti di sidang, asalkan keterangan itu didukung oleh suatu alat bukti yang sah sepanjang mengenai hal yang didakwakan kepadanya;

3) Keterangan terdakwa hanya dapat digunakan terhadap dirinya sendiri;

4) Keterangan terdakwa saja tidak cukup untuk membuktikan, bahwa ia bersalah melakukan perbuatan yang didakwakan kepadanya, melainkan harus disertai dengan alat bukti yang lain.

Dari ketentuan Pasal 189 KUHAP itu dapat disimpulkan, bahwa keterangan terdakwa harus diberikan di depan sidang pengadilan.

Sedangkan keterangan terdakwa yang diberikannya di luar sidang hanya dapat dipergunakan untuk menemukan bukti disidang saja.

Dalam hal terdakwa lebih dari satu orang, maka keterangan dari masing-masing terdakwa hanya berlaku untuk dirinya sendiri. Dengan kata lain keterangan terdakwa yang satu tidak boleh dijadikan alat bukti bagi terdakwa lainya. Keterangan terdakwa saja tidak cukup untuk membuktikan, bahwa terdakwa telah bersalah melakukan suatu tindak pidana, kalau tidak didukung oleh alat bukti lainnya.

Sama halnya dengan tindak pidana lainnya, maka untuk kasus tindak pidana yang berkaitan dengan lingkungan hidup, maka masalah pembuktian juga sangat memegang peran penting. Untuk itu maka pemahaman terhadap hal-hal apa saja yang masuk kategori tindak pidana untuk kasus lingkungan hidup sangatlah penting. Hal ini akan menentukan apakah bisa memintakan pertanggungjawaban kepada pelaku atau tidak. 
Dalam peraturan perundang-undangan yang mengatur tentang lingkungan hidup, disebutkan bahwa tindakan yang dikategorikan sebagai perbuatan yang melanggar ketentuan hukum lingkungan yang bisa menyebabkan pelakunya mendapatkan sanksi pidana adalah perbuatan melakukan pencemaran dan perusakan lingkungan.

Dalam pembahasan ini peneliti akan melakukan perbandingan tentang definisi pencemaran dan perusakan lingkungan menurut UU No. 23 Tahun 1999 dengan UU No. 32 Tahun 2009. Dari definisi tersebut, maka bisa diketahui, apa saja yang menjadi unsur tindak pidananya, kemudian juga bisa diketahui tindakan apa saja yang harus dilakukan untuk membuktikan unsur kesalahan pelaku sehingga pelakunya bisa dimintakan pertanggungjawaban.

Dalam 1 angka (12) UU No. 23 Tahun 1999 definisi "Pencemaran lingkungan hidup adalah masuknya atau dimasukkannya makhluk hidup, zat, energi, dan/atau komponen lain ke dalam lingkungan hidup oleh kegiatan manusia sehingga kualitasnya turun sampai ke tingkat tertentu yang menyebabkan lingkungan hidup tidak dapat berfungsi sesuai dengan peruntukannya." Kemudian menurut Pasal 1 angka (14) UU No. 23 Tahun 1999 definisi "Perusakan lingkungan hidup adalah ukuran batas perubahan-perubahan langsung atau tidak langsung terhadap sifat fisik dan/atau hayatinya yang mengakibatkan lingkungan hidup tidak berfungsi lagi dalam menunjang pembangunan berkelanjutan." Kalau kita cermati bunyi definisi pencemaran lingkungan versi UU No. 23 Tahun 1999, maka unsur tindak pidana terjadi kalau memenuhi dua unsur yaitu:

(1) kalau suatu zat, organisme atau unsur-unsur yang lain (seperti gas, cahaya, energi) telah tercampur ke dalam sumber daya/lingkungan tertentu.

(2) Dan karenanya menghalangi/mengganggu fungsi atau peruntukan daripada sumber daya/lingkungan tersebut.

Kedua unsur tersebut harus terpenuhi semuanya. Jadi kalau kehadiran suatu zat, organisme atau unsur-unsur yang lain (seperti gas, cahaya, energi) telah tercampur ke dalam sumber daya/lingkungan tertentu, walaupun telah menimbulkan perubahan pada unsur lingkungan hidup, seperti perubahan warna atau bentuk atau bau tapi tidak menyebabkan menghalangi/mengganggu fungsi atau peruntukan daripada sumber daya/lingkungan hidup, maka perbuatan tersebut tidaklah termasuk kategori pencemaran lingkungan. Misalnya bernafas. Sekalipun jelas terbukti, dalam proses bernafas, manusia mengambil 02 dari lingkungan dan mengeluarkan zat pencemar yaitu CO2 ke lingkungan, namun perbuatan itu tidak termasuk kategori pencemaran udara karena belum pernah 
terbukti adanya manusia yang dalam proses bernafas mengeluarkan CO2 yang mengakibatkan gangguan bagi unsur lingkungan lainnya.

Kemudian untuk definisi perusakan lingkungan seperti disebutkan di atas, maka untuk bisa dinyatakan telah terjadi tindak pidana perusakan lingkungan menurut UU No. 23 Tahun 1999 terdapat 3 (tiga) unsur, dan sama dengan kasus pencemaran lingkungan, untuk kasus perbuatan perusakan lingkungan, juga dituntut terpenuhinya ketiga unsur tersebut, tanpa ada yang boleh kurang.

3 (tiga) unsur yang harus terpenuhi unsur menentukan telah terjadinya tindakan perusakan lingkungan adalah:

(1) Telah terjadi suatu aktivitas terhadap lingkungan atau kehadiran benda-benda asing ke dalam lingkungan;

(2) menyebabkan timbulnya perubahan pada sifat-sifat fisik dan atau hayati lingkungan;

(3) menimbulkan gangguan pada ekosistem lingkungan, sehingga karenanya fungsi lingkungan sebagai sarana pendukung terlanjutkannya pembangunan tidak atau kurang terpenuhi.

Jadi bisa disimpulkan jenis tindak pidana dalam UU No. 23 tahun 1999 ini termasuk kategori delik materiel. Maksudnya adalah untuk menentukan telah terjadinya suatu tindak pidana atau bukan ditentukan oleh apakah perbuatan yang dilakukan tersebut telah menimbulkan akibat yang dilarang oleh undang-undang. Kalau tidak terjadi akibat yang dilarang, maka perbuatan tersebut bukanlah tidak pidana. Jadi yang dibuktikan di sini adalah bukan hanya masalah perbuatannya yang nyata dilakukan oleh pelaku sebagai perbuatan yang bisa dipertanggungjawabkannya di hadapan hukum pidana tapi juga harus dibuktikan kalau perbuatan tersebut telah menimbulkan akibat yang dilarang oleh undang-undang.

Kemudian menurut Pasal 1 ayat (14) UU No. 32 Tahun 2009 definisi "pencemaran lingkungan adalah masuknya atau dimasukkannya makhluk hidup, zat, energi, dan/atau komponen lain ke dalam lingkungan hidup oleh kegiatan manusia sehingga melampaui baku mutu lingkungan hidup yang ditetapkan." Sedangkan menurut Pasal 1 ayat (16) UU No. 32 Tahun 2009 definisi "Perusakan lingkungan adalah tindakan orang yang menimbulkan perubahan-perubahan langsung atau tidak langsung terhadap sifat fisik, kimia, dan/atau hayati lingkungan hidup sehingga melampaui kriteria baku kerusakan lingkungan hidup." 
Kalau kita cermati bunyi definisi pencemaran lingkungan versi UU No. 32 Tahun 2009, maka unsur tindak pidana terjadi kalau memenuhi unsur yaitu adanya tindakan orang memasukkan makhluk hidup, zat, energi, dan/atau komponen lain ke dalam lingkungan hidup sehingga melampaui baku mutu lingkungan hidup yang ditetapkan. Sedangkan untuk perusakan lingkungan unsurnya adalah adanya tindakan orang yang menimbulkan perubahan-/perubahan langsung atau tidak langsung terhadap sifat fisik, kimia, dan/atau hayati lingkungan hidup sehingga melampaui kriteria baku kerusakan lingkungan hidup.

Dari kedua definisi tersebut di atas, tindak pidana pencemaran dan perusakan lingkungan versi UU No. 32 Tahun 2009 termasuk kategori delik formal, sehingga hanya perlu dibuktikan adanya perbuatan yang dilarang yang mana perbuatan tersebut melampaui nilai ambang batas yang ditentukan oleh peraturan perundang-undangan. Akibat negatif dari suatu tindakan dalam hal ini, tidak perlu dibuktikan. Apakah perbuatan tersebut menimbulkan dampak negatif atau bahkan malah tindakan tersebut menimbulkan dampak positif yaitu memberi manfaat buat lingkungan tetap dimasukkan dalam kategori tindak pidana kalau perbuatan tersebut melampaui nilai ambang batas.

\section{Sinkronisasi Definisi Pencemaran dan Perusakan Lingkungan Hidup menurut UU}

\section{No. 32 tahun 2009 dengan Teori Lingkungan Hidup}

Seperti dijelaskan dalam Bab III tentang kriteria ekologi terjadinya pencemaran dan perusakan lingkungan menurut Otto Soemarwoto lingkungan telah tercemar apabila terpenuhi dua syarat yaitu: “(1). kalau suatu zat, organisme atau unsur-unsur yang lain (seperti gas, cahaya, energi) telah tercampur ke dalam sumber daya/lingkungan tertentu. (2). Dan karenanya menghalangi/mengganggu fungsi atau peruntukan daripada sumber daya/lingkungan tersebut."21 Kedua syarat tersebut mutlak harus dipenuhi, karena bila hanya nomor satu saja maka baru terjadi pengotoran yaitu perubahan kualitas sumber daya sebagai akibat tercampurnya bahan lain tanpa mengganggu peruntukan/kegunaannya. ${ }^{22}$ Kemudian menurut Harun M. Husein, secara ekologis, lingkungan telah rusak apabila:

Telah terjadi suatu aktivitas terhadap lingkungan atau kehadiran benda-benda asing ke dalam lingkungan, menimbulkan gangguan pada ekosistem lingkungan,

21 Otto Soemarwoto, Op.Cit, h. 17

22 NHT. Siahaan, Op.Cit. h. 159-160 
yang menyebabkan timbulnya perubahan pada sifat-sifat fisik dan atau hayati lingkungan, sehingga karenanya fungsi lingkungan sebagai sarana pendukung terlanjutkannya pembangunan tidak atau kurang terpenuhi. ${ }^{23}$

Kalau kita cermati kriteria pencemaran dan perusakan secara ekologis di atas, maka bisa disimpulkan, kriteria pencemaran dan perusakan lingkungan yang sinkron adalah kriteria pencemaran dan perusakan lingkungan versi UU No. 23 Tahun 1999, sementara kriteria pencemaran dan perusakan lingkungan versi UU No. 32 Tahun 2009 tidak sinkron.

Secara ekologis pencemaran dan perusakan adalah dampak/negatif dari suatu perbuatan yang menimbulkan resiko atau kerugian buat lingkungan hidup. Wujud dari dampak negatif tersebut adalah turunnya atau tidak berfungsinya lingkungan hidup sebagaimana mestinya untuk mendukung kehidupan. Jadi hanya dengan melihat suatu perbuatan walaupun secara teori perbuatan tersebut mengandung resiko berdampak negatif, tetap tidak bisa langsung dikategorikan pasti mengakibatkan terjadinya pencemaran atau perusakan. Jadi sekali lagi pencemaran dan perusakan adalah akibat dari suatu perbuatan.

\section{KESIMPULAN}

1. Hasil perbandingan kriteria pencemaran dan kerusakan lingkungan, versi UU No. 23 tahun 1999 dengan UU No. 32 Tahun 2009 menghasilkan suatu perbedaan dalam menentukan suatu tindak pidana. Versi UU No. 23 Tahun 1999, tindak pidana pencemaran dan perusakan lingkungan termasuk kategori delik materiel, sehingga dalam proses pembuktiannya dituntut dua hal yaitu terbukti perbuatan tersebut dilakukan oleh pelaku yang mampu bertanggungjawab dan harus pula dibuktikan perbuatan tersebut menimbulkan akibat yang dilarang oleh undang-undang. Sedangkan versi UU No. 32 Tahun 2009, tindak pidana pencemaran dan perusakan lingkungan termasuk kategori delik formal, sehingga hanya perlu dibuktikan suatu perbuatan yang dilarang saja.

2. Kriteria pencemaran dan perusakan lingkungan menurut UU No. 32 Tahun 2009 bertentangan atau tidak sinkron dengan kriteria berdasarkan teori lingkungan hidup atau kriteria secara ekologis.

23 Harun. Husein, Op.Cit, h. 64 


\section{Daftar Pustaka}

Erliany, Rangkungan Materi Hukum Pidana, BanjarmasinL STIH Sultan Adam, 2014.

Hadi, P. Sudharto, Manusia dan Lingkungan, Semarang: Badan Penerbit Universitas Diponegoro, 2000.

Hardjasoemantri, Koesnadi, Hukum Tata Lingkungan, Yogyakarta: Gadjah Mada University Press, 1994

Husein, Harun M., Lingkungan Hidup (Masalah, Pengelolaan dan Penegakan Hukumnya, Jakarta: Bumi Aksara, 1995

Marzuki, Peter Mahmud, Penelitian Hukum, Jakarta: Kencana Prenada Media Group, 2011. Pengantar Ilmu Hukum, Jakarta: Kencana Prenada Media Group, 2008.

Moeljatno, Perbuatan Pidana dan Pertanggungan Jawab Dalam Hukum Pidana. Yogyakarta: Yayasan Badan Penerbit Gajah Mada, 1959.

Salim, Emil, Pembangunan Berwawasan Lingkungan, Jakarta: LP3ES, 1993.

Siahaan, NHT., Ekologi Pembangunan dan Hukum Tata Lingkungan, Jakarta: Erlangga, 1987.

Siombo, Marhaeni Ria, Hukum Lingkungan dan Pelaksanaan Pembangunan Berkelanjutan di Indonesia, Jakarta: Gramedia Pustaka Umum, 2012.

Soemarwoto, Otto, Ekologi, Lingkungan hidup dan Pembangunan, Jakarta: Djambatan, 1989.

Songgono, Bambang, Metodologi Penelitian Hukum, Jakarta: PT. Raja Grafindo Persada, 1998.

Susan, Hukum Acara Pidana, Banjarmasin: STIH Sultan Adam, 2014. 